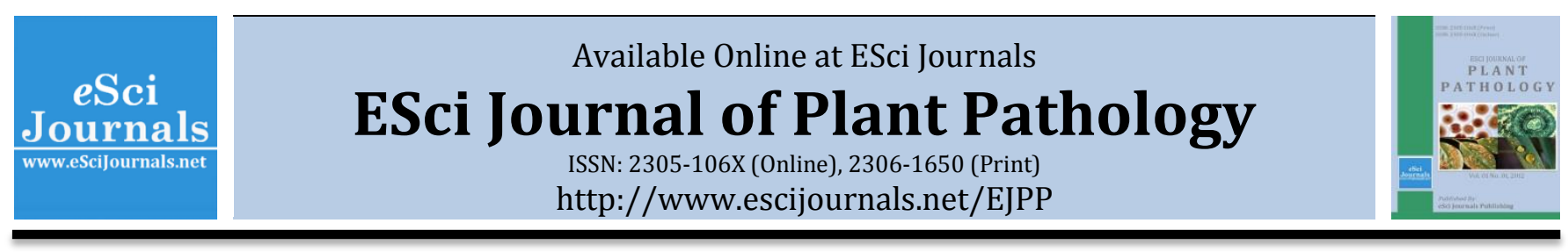

\title{
SEROLOGICAL IDENTITY OF POTATO VIRUS X (PVX) AND PCR CHARACTERIZATION OF ITS COAT PROTEIN (CP) GENE
}

\author{
aQudsia Nosheen, bShahid Hameed, aSardar M. Mughal, aMuhammad F. Abbas \\ a Department of Plant Pathology, Pir Mehr Ali Shah Arid Agriculture University Rawalpindi, Pakistan \\ b Crop Disease Research Institute, National Agricultural Research Centre Islamabad, Pakistan.
}

\section{A B S T R A C T}

Potato virus $\mathrm{X}$ (PVX) is among top ten most economically damaging plant viruses in the world and its increasing incidence is getting an alarming situation in potato crop of Pakistan. During two consecutive years (2010-11 and 201112), the incidence of PVX was recorded in potato fields at Rawalpindi, Islamabad, Faisalabad and Sahiwal. The samples were collected and subjected to Double Antibody Sandwiched (DAS) Enzyme Linked Immunosorbant Assay (ELISA) and average incidence of PVX was determined about $16.86 \%\left(\mathrm{OD}_{405 \mathrm{~nm}} 1.38\right)$ during $2010-11$ and $27.10 \%\left(\mathrm{OD}_{405 \mathrm{~nm}}\right.$ 0.479) in 2011-12. The infectivity of the virus was assayed through mechanical inoculation on Nicotiana tabacum cv. Samsun, N. rustica, Datura stramonium, Chenopodium sp. Gomphrena and Capsicum annuum producing local lesion, mosaic and mottling symptoms. Coat protein (CP) gene specific sense and antisense primer successfully amplified a 750bp fragments through Polymerase Chain Reaction (PCR) assay.

Keywords: Potato, ELISA, PCR, Infectivity assay, CP gene.

\section{INTRODUCTION}

Potato (Solanum tuberosum L.) is most widely grown tuber crop in the world. It ranks fourth among food crops after wheat, maize and rice and fifth in total production in Pakistan. It is the highest in dry matter production, edible energy, nutritional value and protein per unit area than wheat, rice and maize and it provides 12-15 times more yield per unit area as compared with cereals (Rauscher et al., 2006). Soil and climatic conditions prevalent in Pakistan are highly conducive for the production of three crops of potato a year, i.e. autumn and spring crops in the plain and summer crop in the hills (Zanoni, 1991). In Pakistan, potato is cultivated over an area of 127.7 thousand hectares and annual production is 3726.5 thousand tons which is very low as compared to other potato growing countries (GOP, 2011) while bacteria, nematode (Gondal et al., 2012; Praveen et al., 2013), fungus (Ashraf et al., 2012; Mehboob et al., 2013) and virus (Abbas et al., 2012; Gul et al., 2013) along with a biotic factors play a pivotal role

\footnotetext{
* Corresponding Author:
}

Email: nosheen.20@gmail.com

(C) 2013 ESci Journals Publishing. All rights reserved. for yield reduction in potato crop of Pakistan.

Introduction of new and high yielding varieties from abroad and improved agronomic practices have undoubtedly enhanced potato production in Pakistan but average yield is still lower than the other potato growing countries in the world (GOP, 2011). This is mainly attributed to the prevalence of several virus diseases inadvertently introduced in the country from time to time. So far, more than seven viral diseases have been observed on potato crop in the country, which includes Potato virus X (PVX), Potato virus Y (PVY), Potato leaf roll virus (PLRV), Potato virus A (PVA), Potato virus M (PVM), Potato virus S (PVS), Potato moptop virus (PMTV), Potato spindle tuber viroid (PSTVd) and some phytoplasmal diseases (Mughal et al., 1989) collectively causing $83 \%$ loss in potato production (Mughal and Khalid, 1985). Among the viral diseases, PVX is important, widespread and responsible for significant losses in potato production in the world including Pakistan (Abbas and Hameed, 2012). It induces mosaic symptoms and it is involved in degeneration of seed potato. The losses inflicted by PVX alone in Pakistan range between 2-25\%. The virus 
isolated is identified on the basis of biological, physical and serological properties and production of monoclonal antibodies (Khalid et al., 1989).

PVX is reported to infect more than 240 species in 16 families of Solanaceae, Amaranthaceae, Chenopodiaceae, Cucurbitaceae and Fabaceae (Jung et al., 2000). Diagnostic hosts of PVX include Nicotiana tabacum, $N$. clevelandii, N. glutinosa, N. debneyi, Physalis floridana, Lycopersicon lycopersicum, Datura stramonium, D. metal, Gomphrena globosa, Chenopodium amaranticolor, C. quinoa and Phaseolus vulgaris (Brunt et al., 1996). Virus spreads through contact, mechanical and aphid transmission (Bercks, 1970). The common isolate of PVX is highly immunogenic, induces mild mosaic or latent infection, but other strains cause severe mosaic, crinkling or even rugosity (Manzer et al., 1978). PVX-KO strains or other isolates caused necrotic spots on C. amaranticolor and C. quinoa, local lesions on $D$. stramonium and systemic mosaic and vein clearing on $N$. tabacum; typical mosaic or mottling and vein clearing in D. stramonium after 14 days of inoculation (Bercks, 1970; Jung et al., 2000).

The PVX is a virus with single stranded positive sense RNA genome having a cap structure at 5' end and poly (A) tail at $3^{\prime}$ terminus (Sonenberg, 1978). The 3' terminus encodes a CP gene which is involved in various stages of infection cycle. The virus particles by weight contain 6\% nucleic acid and approximately 94\% of protein (Tollin et al., 1967). It is strongly immunogenic and easily detected by various serological tests as ELISA and time-resolved fluoroimmunoassay (Sinijarv et al., 1988). Monoclonal antibodies are used to identify three antigenic determinants on coat protein of virus (Koenig and Torrance, 1986). ELISA developed by Clark and Adams (1977) has been routinely used to test and identify viruses. A rapid and sensitive assay using RTPCR-capture probe hybridization (RT-PCR-ELISA) has been applied successfully for quick detection and characterization of an isolate of PVX in Egypt. Soliman et al. (2000) used specific oligonucleotide primers which were designed for the amplification from the $\mathrm{CP}$ gene of PVX genome in RT-PCR assays.

\section{MATERIALS AND METHODS}

During the year 2010-11 and 2011-12, the symptomatic and plants suspected to be infected by virus were collected in four potato cultivated areas: Rawalpindi, Islamabad, Faisalabad and Sahiwal. A total of 332 samples of 6-8 weeks old field growing potato plants were collected on the basis of virus and viral like symptoms. A single sample was consisted of three single leaflets taken from top, middle and bottom and placed in polythene sample bag. Samples were appropriate labeled to indicate location, sample number and date of collection.

Serological and biological confirmation: The collective samples were subjected to DAS-ELISA as described by Clark and Adams (1977) using BIOREBA kit and polystyrene plastic plate with $U$ wells. Immunoglobulin G (IGg) of PVX were diluted (1:1000) in coating buffer and diluted IgG $(100 \mu \mathrm{l} /$ well $)$ was loaded to each well. The test samples were homogenized in the extraction buffer (1:10) and homogenate $(100 \mu \mathrm{l} /$ well) was added to each well while coated plates were incubated at $4^{\circ} \mathrm{C}$ overnight. This was followed by addition of 100ul/well alkaline phosphate enzyme (ALKP) conjugated IgG diluted at 1:1000 and plate was kept at room temperature for $3 \mathrm{~h}$. After addition of each reactant, plates were tightly covered and placed in a moist chamber before incubation, and between two steps were emptied and washed 3 times at $3 \mathrm{~min}$ intervals with washing buffer and dried on paper towel. After final washing, $150 \mu \mathrm{l}$ of freshly prepared pnitrophenyl phosphate substrate $(1 \mathrm{mg} / \mathrm{ml})$ was added to each well and the plates were incubated in dark at room temperature. Yellow color development was visually assessed after 1 hour as mild (+), moderate $(++)$, strong (+++) and no reaction (-). Optical density $\left(\mathrm{OD}_{405 \mathrm{~nm}}\right)$ of yellow color was measured at $405 \mathrm{~nm}$ in an ELISA reader (EPSON LX-300). Mean $\mathrm{OD}_{405}$ values of healthy samples and extraction buffer used as control, and their standard deviation was calculated and multiplied by 3 (Clark and Adams, 1977). Any value above or equal the standard deviation was taken as positive. Only ELISA positive potato plants were included in calculating percentage incidence of PVX.

Test plants of C. amaranticolor, N. rustica, N. tabacum cv. Samsun, $N$. benthamiana, D. stramonium, G. globosa and $C$. annuum were raised in an insect-free glasshouse maintained at $30 \pm 2{ }^{\circ} \mathrm{C}$. Inoculum was prepared by grinding infected tissue in a pestle and mortar in presence of $0.02 \mathrm{M}$ phosphate buffer, $\mathrm{pH} 7.2(1 \mathrm{~g} / 1 \mathrm{ml})$. Test plants were lightly dusted with 600-mesh carborundum powder and inoculated mechanically with infective sap by forefinger. Plants were rinsed with tap water to remove superfluous inoculum and maintained in the glasshouse for symptom expression. 
PCR characterization of CP gene: Leaf tissue (100mg) of DAS-ELISA confirmed samples was crushed in an ice chilled auto clave pestle and mortar with liquid nitrogen while TRI Reagent $(1 \mathrm{ml})$ was added and the homogenate was stored on ice for $5 \mathrm{~min}$. Homogenate was transferred into new $2 \mathrm{ml}$ micro-centrifuge tubes containing chloroform $(0.2 \mathrm{ml})$ and tubes were shaken vigorously for $15 \mathrm{sec}$. The resulting mixture was stored on ice for $10 \mathrm{~min}$ and centrifugation was performed at $12,000 \mathrm{rpm}$ for $15 \mathrm{~min}$. The aqueous phase was transferred to a fresh tube containing isopropanol $(0.5$ $\mathrm{ml}$ ) while the mixture was stored on ice for $10 \mathrm{~min}$ and centrifuged at 12,000 rpm for $8 \mathrm{~min}$. The supernatant was removed, total RNA pellet was washed with $1 \mathrm{ml}$ ethanol (75\%) and tubes were centrifuged at $7500 \mathrm{rpm}$ for $5 \mathrm{~min}$ while all centrifugation was done at $4^{\circ} \mathrm{C}$. The ethanol was briefly air dried and $20 \mu \mathrm{l}$ of Diethylpyrocarbonate (DEPC) treated water was added after drying the pellet at room temperature. The available sequences of CP gene of PVX were downloaded from National Centre for Biotechnological Information (NCBI) and the consensus sequences were selected for sense (GACCTCGAGATGTCAGCACCAGCTAG) and antisense primer (GGCGAATTCTTATGGTGGTGG TAGAGTG) end of CP gene. The cDNA was synthesized using Revert Aid Reverse Transcriptase with total nucleic acid and CP gene specific antisense primer. A
$50 \mu \mathrm{l}$ PCR reaction mixture contained $2 \mu \mathrm{l}$ of cDNA template, $1 \mathrm{X}$ Taq reaction buffer, $1.5 \mathrm{mM}$ of $\mathrm{MgCl}_{2}$, $0.2 \mathrm{mM}$ of dNTPs, 2 unit of Taq DNA polymerase and both primers $(10 \mathrm{Pmol})$. The PCR conditions were $94^{\circ} \mathrm{C} / 3 \mathrm{~min}$ followed by 35 cycles of denaturation at $94^{\circ} \mathrm{C} / 30 \mathrm{sec}$, annealing at $51^{\circ} \mathrm{C} / 30 \mathrm{sec}$ and extension at $72^{\circ} \mathrm{C} / 1 \mathrm{~min}$ while final extension was performed at $72^{\circ} \mathrm{C} / 10 \mathrm{~min}$. A negative control (without template) was always included in PCR. PCR amplified products were analyzed by electrophoresis on 1\% agarose gel in TBE buffer (89mM Tris, $89 \mathrm{mM}$ boric acid, $2 \mathrm{mM}$ EDTA) stained with ethidium bromide and visualized under UV illumination light. CP gene fragment size was determined using the $1 \mathrm{~kb}$ DNA Ladder.

\section{RESULTS AND DIUSCUSSION}

Status of PVX in the main potato growing areas of the Punjab was assessed and examined for two consecutive years (2010-11 and 2011-12). Each year, 166 potato leaf samples were collected on the basic of PVX symptoms and subjected to DAS-ELIS. The presence of yellow and white color in ELISA plates clearly indicated the presence or absence of PVX in potato samples respectively (Fig 1) and 28 samples in the first and 42 samples in the second year found to be ELISA positive (Table 1). On this basis, average incidence of PVX was found to be $16.86 \%$ in $2010-11$ and $27.10 \%$ in $2011-12$ with significant differences (Table 1).

Table1. Percent incidence of PVX and $\mathrm{OD}_{405} \mathrm{~nm}$ values in ELISA Reaction

\begin{tabular}{|c|c|c|c|c|c|c|}
\hline \multirow{2}{*}{$\begin{array}{c}\text { Year } \\
\text { Location }\end{array}$} & \multicolumn{2}{|r|}{$2010-11$} & \multirow[b]{2}{*}{$\begin{array}{l}\text { Percentage } \\
\text { infection }\end{array}$} & \multirow[b]{2}{*}{$\begin{array}{c}\text { No. of } \\
\text { samples } \\
\text { +ve/tested }\end{array}$} & \multicolumn{2}{|c|}{ 2011-12 } \\
\hline & $\begin{array}{c}\text { No. of } \\
\text { samples } \\
+ \text { +ve/tested }\end{array}$ & OD values & & & OD values & $\begin{array}{c}\text { Percentage } \\
\text { infection }\end{array}$ \\
\hline Rawalpindi & $7 / 51$ & $1.760(0.106)$ & 14.00 & $8 / 51$ & $0.432(0.046)$ & 16.00 \\
\hline Islamabad & $5 / 40$ & $1.351(0.080)$ & 13.00 & $9 / 40$ & $0.438(0.146)$ & 23.00 \\
\hline Faisalabad & $12 / 47$ & $2.150(0.340)$ & 26.00 & $22 / 47$ & $0.766(0.075)$ & 36.50 \\
\hline Sahiwal & $4 / 28$ & $0.272(0.054)$ & 15.00 & $7 / 28$ & $0.282(0.050)$ & 17.00 \\
\hline Total & $28 / 166$ & - & $68 \%$ & $42 / 166$ & - & $92 \%$ \\
\hline Mean & $7 / 41.5$ & $1.380(0.266)$ & 16.86 & $11.5 / 41.5$ & $0.479(0.078)$ & 27.10 \\
\hline C.D.at $\mathrm{P}=$ & $.5-$ & $.345(0.066)$ & 6.52 & - & $0.120(0.019)$ & 10.48 \\
\hline
\end{tabular}

During the year 2011-12, the disease incidence increased $2 \%$ in Rawalpindi and Sahiwal, $10 \%$ in Islamabad and $9.5 \%$ in Faisalabad as compared to the year 2010-11. It was observed that the virus incidence increased by $10.24 \%$ in the second year which may be attributed to use of infected seed tubers or spread of virus by contact. It confirms that incidence of PVX is not static but fluctuates and increasing incidences are responsible for low yields. Similar findings were made by Hay et al. (2007) who recorded 10\% increase of PVX within two years in Australia but Ahmad et al. (2003) and Abdullah (1992) reported $13.8 \%$ and 5\%, respectively. Under average conditions, PVX results in 515\% yield losses (Hay et al., 2007). 


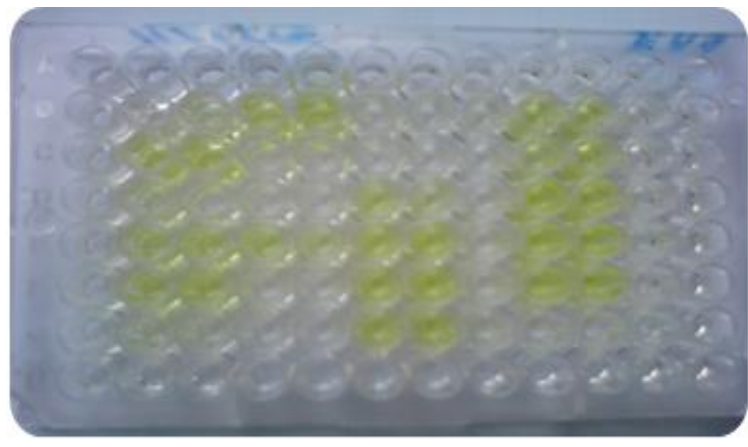

Fig 1: Yellow and white color in ELISA plate indicate the presence and absence of PVX respectively.

Under severe conditions of infection as high as 50-70\% losses can occur (Mughal and Khalid, 1985). On average basis only $22 \%$ samples were ELISA positive and the rest $78 \%$, although symptomatic or suspected to be virusinfected were negative, indicating the involvement of other viruses as PVS, PVA, PVY and PVM etc. Therefore, as already stated by Hamilton et al. (1981) and Bock (1982), symptom expression is not usually a precise indication of virus identity and its interpretation should be treated with caution. Brunt et al. (1996) have reported that PVX has a wide host range but under the local conditions natural host range of PVX seems to be narrow. We restricted this aspect to infectivity assay on potato, capsicum, tobacco or to some experimental plants (Table 2). High incidence of PVX, however, indicates that different strains of PVX are present in Pakistan which needs to be isolated and characterized.

Table 2 Infectivity of PVX on some selected indicator host plants.

\begin{tabular}{lcc}
\hline \multirow{2}{*}{\multicolumn{1}{c}{ Host species }} & \multicolumn{2}{c}{ Reaction } \\
\cline { 2 - 3 } & Local & Systemic \\
\hline Chenopodium quinoa & LL & - \\
Nicotiana rustica & LL & Mo \\
N. tabacum cv. Samsun & LL & Mo \\
Gomphrena globosa & NLL & - \\
Capsicum annuum & Mo & Mo , Mot \\
\hline
\end{tabular}

Abbreviations: $\mathrm{LL}=$ Local lesion, $\mathrm{Mo}=$ Mosaic, Mot= Mottling, - = not infected or no symptoms. NLL= necrotic local lesions.

New specific, sensitive, efficient and more reliable molecular tools (PCR) were introduced and CP gene specific sense and antisense primer successfully amplified the virus. Few symptomless and ELISA negative plants produced an expected band through PCR while no band was observed in negative control. The rapid evolution of virus and the continuous emergence of the recombinant strains, however, make it necessary to update these assays at nucleotide level (Ali et al., 2010). CP gene specific primers successfully amplified $750 \mathrm{bp}$ fragment of CP gene and any nonspecific bands were not found in any sample (Fig 2).

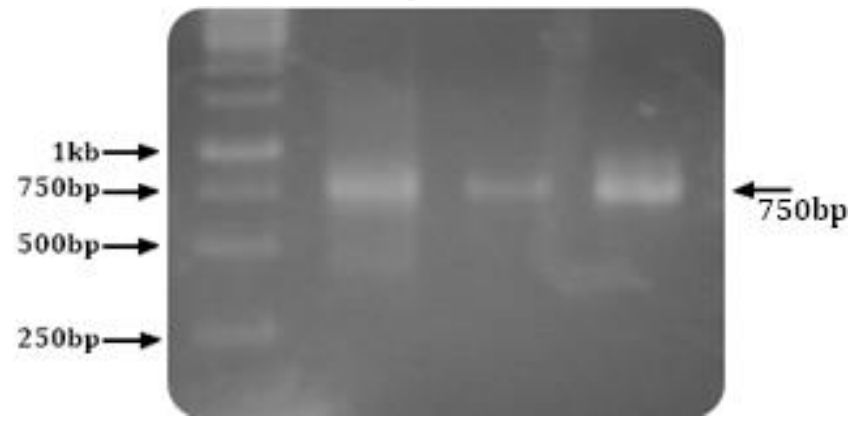

Fig 2: PCR-Amplification of Potato virus $\mathrm{X}$ coat protein gene.

Resistant or tolerant potato varieties against viruses, meristem culture, treatment with chemotherapy and thermotherapy, insect pests along with weeds control may play a pivotal role in reducing yield losses of potato crop. Molecular identification of these viruses will also be helpful in developing an integrated control strategy and resistance source against potato virus diseases and thus improve the farmer's income. The results obtained are in close conformity with those of Soliman et al. (2000). Overall results suggested that sequencing of PVX-CP gene should be determined for further studies.

\section{REFERENCES}

Abbas, M.F., S. Hammed, C.A. Rauf, Q. Nosheen, A. Ghani, A. Qadir and S. Zakia. 2012. Incidence of six viruses in potato growing areas of Pakistan. Pak. J. Phytopath., 24 (1): 44-47.

Abbas, M.F and S. Hameed. 2012. Identification of disease free potato germplasm against potato viruses and PCR amplification of potato virus X. Int. J. Biol. Biotech., 9 (4): 335-339.

Abdullah, M. 1992. Status of viral diseases of potatoes in Pakistan and their detection with ELISA technique in Proc."Workshop on Seed Potato Health". FSC and RD Islamabad. pp 34-42.

Ahmad, W., D. Iman and N.U. Jan. 2003. Recent trends of potato viruses prevailing in potato growing areas of Punjab. Pak. J. Phytopathol., 15: 21-24.

Ali, M.C., T. Maokac, K.T. Natsuakid and T. Natsuakia. 2010. The simultaneous differentiation of Potato virus $\mathrm{Y}$ strains including the newly described strain PVYNTN-NW by multiplex PCR assay. J. Virol. 
Method., 165: 15-20.

Ashraf, A., C.A. Rauf, M.F. Abbas and R. Rehman. 2012. Isolation and identification of Verticillium dahliae causes wilt on potato in Pakistan. Pak. J. Phytopath., 24 (2): 112-116.

Bercks, R. 1970. CMI/AAB. Descriptions of Plant viruses. Potato virus X. No. 4. Culross and Son Ltd. Scotland.

Bock, K.P. 1982. Identification and partial characterization of plant viruses in the tropic Trop. Pest Man., 28: 399-411.

Brunt, A.A., K. Crabtree, M.J. Dallwitz, A.J. Gibbs and L. Watson. 1996. Viruses of plants descriptions and lists from the VIDE database. CAB International, Wallingford. pp 1484.

Clark, M.F and A.N. Adams. 1977. Characteristics of the microplate method of Enzyme-linked immunosorbent assay for the detection of plant virus. J. Gen. Virol., 34: 475-483.

Gul, Z., A.A. Khan, A.U.R. Khan and Z.U. Khan. 2013. Incidence of potato viruses in different districts of Khyber Pakhtunkhawa, Pakistan. ESci J. Plant Pathol., 02 (01). 32-36.

Gondal, A.S., N. Javed, S.A. Khan and S. Hyder. 2012. Genotypic diversity of potato germplasm against root knot nematode (Meloidogyne incognita) infection in Pakistan. ESci J. Plant Pathol., 01: 2738.

GOP. 2011. Economic Survey of Pakistan, 2010-11. Finacae Division, Economic Wing, Islamabad, 2122.

Hamilton, R.I., J.R. Edwadrson, R.I.B. Francki, H.T. Hsu, R. Hull, R. Koenig and R.G. Milni. 1981. Guidelines for the identification and characterization of plant viruses- review article. J. Gen. Virol., 54: 223-241.

Hay, F.S., S.J. Lambert, S.J. Pethybridge and C.R. Wilson. 2007. Spatiotemporal spread of Potato virus $S$ and Potato virus $\mathrm{X}$ in seed potato in Tasmania, Australia. Plant Management Network.

Jung, H.W., W.S. Yun, H.W. Seo, Y. Hahm and K. Kim. 2000. Characterization and partial nucleotide sequence of potato Virus $\mathrm{X}$ isolated from potato in Korea. J. Plant Pathol., 16 (2): 110-117.

Khalid, S., S.M. Mughal and T. Shaheen. 1989. Occurrence and some properties of PVX in Pakistan. Pak. J. Phytopath., 1 (2): 9-19.

Koenig, R and L. Torrance. 1986. Antigenic Analysis of Potato Virus $\mathrm{X}$ by means of Monoclonal
Antibodies. J. Gen. Virol., 67: 2145-2151.

Manzer, F.E., D.C. Merriam and P.R. Helper. 1978. Effects of two strains of potato virus $\mathrm{X}$ on yields of Russet Burbank, Kennebec and Katahdin cultivars in Maine. J. Potat., 55: 601-609.

Mehboob, S., M.A. Khan, A. Rehman and M. Idrees. 2013. Role of epidemiological and biochemical factors against early blight of potato. ESci. J. Plant Pathol., 02 (01). 08-13.

Mughal, S.M and S. Khalid. 1985. Virus diseases in relation to potato production in Pakistan. Proc. Natl. Sem. on potato in Pakistan. April 2-4, PARC, Islamabad. pp: 153-165.

Mughal, S.M., S. Khalid, T.S. Gillani and A. Devaux. 1989. Detection of potato viruses in Pakistan. Proc. Asian Potato Assoc. 2nd triennial Conf., June. 1226, Kunming, China. pp: 189-190.

Parven, N., T. Mukhtar, M.F. Abbas and C.A. Rauf. 2013. Management of root knot nematode with marigold (Tagetes erecta L.) and antagonistic fungus Paecilomyces lilacinus (Thom) Samson in tomato crop. Int. J. Biol. Biotech., 10 (1): 61-66.

Rauscher, G.M., C.D. Smart, I. Simko, M. Bonierbale, H. Mayton, A. Greenland and W.E. Fry. 2006. Characterization and mapping of RPi-ber, a novel potato late blight resistance gene from Solanum berthaultii. Theor. Appl. Genet., 112: 674-687.

Sinijarv, R., L. Jarvekulg, E. Andreeva and M. Saarma. 1988. Detection of Potato Virus X by One Incubation Europium Time-resolved Fluoroimmunoassay and ELISA. J. Gen. Virol., 69: 991-998.

Soliman, A.M., A.A. Shalaby, B.N. Barsoum, G. Mohamed, M.K. Nakhla, H.M. Mazyad and D.P. Maxwell. 2000. Molecular characterization and RT-PCR-ELISA detection of a potato virus $\mathrm{X}$ (PVX) isolate from Egypt. Ann. Agric. Sci., 4: 1791-1804.

Sonenberg, N., A.J. Shatkin, R.P. Ricciardi, M. Rubin and R.M. Goodman. 1978. Analysis of terminal structures of RNA from Potato Virus X. Nucleic Acids Res., 5: 2501-2512.

Tollin, P., H. Wilson, D. Young, J. Cathro and W. Mowat. 1967. X-ray diffraction and electron microscope studies of narcissus mosaic virus and comparison with potato virus X. J. Mol. Biol., 26: 353-355.

Zanoni, U. 1991. Potato Atlas and Compendium of Pakistan. PPDP/PARC, Islamabad, Pakistan. Pp 258. 